\title{
Solução (Química)
}

\author{
Luís Spencer Lima \\ Faculdade de Ciências da Universidade do Porto
}

luisspencerlima@gmail.com

\section{CITAÇÃO \\ Lima, L.S. (2013) \\ Solução (Química), \\ Rev. Ciência Elem., V1(01):081. \\ doi.org/10.24927/rce2013.081}

\section{EDITOR}

José Ferreira Gomes,

Universidade do Porto

\section{RECEBIDO EM}

14 de outubro de 2009

\section{ACEITE EM}

14 de julho de 2010

\section{PUBLICADO EM}

23 de agosto de 2010

\section{COPYRIGHT}

(C) Casa das Ciências 2019.

Este artigo é de acesso livre, distribuído sob licença Creative

Commons com a designação CC-BY-NC-SA 4.0, que permite a utilização e a partilha para fins não comerciais, desde que citado 0 autor e a fonte original do artigo.

\section{rce.casadasciencias.org}

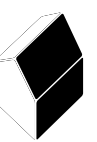

Quando uma substância se dissemina no seio de outra, forma-se uma dispersão. Quando as dimensões das partículas são inferiores a um nanómetro $\left(10^{-9} \mathrm{~m}\right)$, não se pode distinguir a substância dispersa da substância dispersante e a dispersão designa-se solução. Uma solução é uma mistura homogénea de duas ou mais substâncias, na qual só se consegue observar uma única fase, mesmo ao microscópio.

Em geral, associa-se o termo solução à dissolução de um sólido num líquido, por exemplo, cloreto de sódio ou sacarose em água. As soluções aquosas são as mais vulgares, mas existem diversos tipos de soluções: um sólido num sólido (ligas metálicas como bronze, latão ou aço), um líquido num sólido (mercúrio em ouro, hexano em parafina sólida), um líquido num líquido (acetona em água, benzeno em tolueno), um gás num sólido (hidrogénio num metal), um gás num líquido (dióxido de carbono ou oxigénio em água) ou um gás num gás (o ar é uma solução gasosa maioritariamente constituída por diazoto, dioxigénio e árgon).

Nas soluções, a substância na qual se dispersa(m) outro(s) designa-se por solvente e todos os outros componentes são designados por solutos. 0 solvente tem sempre o mesmo estado físico da solução e, normalmente, é a substância presente em maior quantidade. No caso de soluções em que as substâncias estão presentes em proporções idênticas, considera-se solvente o componente mais volátil, isto é, com menor ponto de ebulição.

A composição quantitativa de uma solução pode ser expressa de diversas formas: concentração ou concentração molar do soluto $(c)$, concentração mássica do soluto $(\gamma)$, molalidade $(m)$, fração molar $(x)$, fração mássica $(w)$ e fração volúmica $(\phi)$. A fração mássica é muitas vezes expressa como percentagem em massa $(\% \mathrm{~m} / \mathrm{m})$, partes por milhão $(\mathrm{ppm})$ e partes por bilião (ppb) e a fração volúmica é muitas vezes expressa como percentagem em volume $(\% V / V)$ e partes por milhão em volumes (ppmV).

A massa máxima de soluto que é possível dissolver na unidade de volume de solvente, formando-se uma solução saturada, denomina-se solubilidade. Isto significa que, no caso das soluções sólido-líquido, uma solução saturada não tem capacidade para dissolver mais soluto adicionado, formando-se um depósito sólido. Considere-se a dissolução do cloreto de sódio em água. Este processo conduz à formação de uma solução (insaturada) até atingir o valor da sua solubilidade (359 g por litro de solução, a $25^{\circ} \mathrm{C}$ ). Nesta altura, forma-se uma solução saturada: a adição de mais cloreto de sódio não aumenta a quantidade de soluto dissolvido.

Contudo, existem casos em que é possível obter soluções em que a quantidade de solu- 
to presente é superior à sua solubilidade durante um certo tempo até que o equilíbrio se restabelerça e se deposite o excesso de soluto. Estas soluções denominam-se soluções sobressaturadas. As bebidas gaseificadas constituem um bom exemplo da formação deste tipo de soluções. 0 dióxido de carbono é dissolvido em água a alta pressão até atingir a saturação. Ao colocar esta solução à pressão atmosférica (abertura do recipiente que contém a bebida), como a solubilidade do gás é bastante menor, este escapa-se através da superfície do líquido, mas, como este processo é lento, por momentos, obtem-se uma solução sobressaturada. Fenómeno idêntico se verifica na cristalização, em que se podem ter soluções sobressaturadas até que, por introdução de impurezas ou contacto com objetos irregulares (scratching), ocorre rapidamente a cristalização. 